\title{
The influence of nutrient addition on the invasion of Spartina alterniflora towards the non-tidal wetlands in the Chinese Yellow River delta
}

\author{
Liwen Zhang ${ }^{1} \cdot$ Bingchen Wang ${ }^{1,2}$ \\ Received: 13 January 2019 / Revised: 18 April 2019 / Accepted: 23 April 2019 / Published online: 11 May 2019 \\ (C) Springer Nature B.V. 2019
}

\begin{abstract}
Spartina alterniflora is a notoriously invasive species in the low marsh of China, and meanwhile anthropogenic eutrophication is an urgent and prevalent environmental problem in the coastal wetlands. Soils in the coastal wetland are nutrient-poor, nutrient enrichment may enhance the spread of S. alterniflora towards the non-tidal marsh of the Yellow River Delta. We conducted a 2year transplant and nutrient addition field experiment to investigate the influence of nutrient enrichment and interspecific interactions on the performance (growth, survival or inflorescence) of S. alterniflora. We found that nutrient addition and species competition did not have significant effects on the variation in performances of $S$. alterniflora. However, vegetative zones (Suaeda salsa and Phragmites australis), years (2013 and 2014) significantly contributed to the variation. The biomass per stem, survival and inflorescence were much higher in the $P$. australis than the $S$. salsa zone (biomass per stem: $1.86 \pm 0.17 \mathrm{~g}$ vs. $0.82 \pm$ 0.15 g; survivorship: $79 \%$ vs. $36 \%$; inflorescence: $40 \%$ vs. $2 \%$ ), and in 2013 than 2014 (biomass per stem: $1.72 \pm 0.19 \mathrm{~g}$ vs. 0.91 $\pm 0.13 \mathrm{~g}$; survivorship: $65 \%$ vs. $50 \%$; inflorescence: $36 \%$ vs. $6.94 \%$ ), which may be due to the combination of less flooding frequency and high salinity in the $S$. salsa zone and year 2014. These findings implied that eutrophication may not enhance the spread of $S$. alterniflora towards the non-tidal wetlands in the Chinese Yellow River Delta.
\end{abstract}

Keywords Spartina alterniflora $\cdot$ Nitrogen addition $\cdot$ Phosphorous addition $\cdot$ Yellow River Delta $\cdot$ Invasive species

\section{Introduction}

Coastal wetlands provide a diverse range of ecosystem services, for example, the ability to sequester excess nutrients from upland anthropogenic sources and alleviate the effects of eutrophication on marine ecosystems (Brin et al. 2010; Sousa et al. 2008). However, the increased nutrient inputs into coastal wetlands have led to the eutrophication of water and soil (Howarth et al. 2000). This eutrophication influences species interactions,

Electronic supplementary material The online version of this article (https://doi.org/10.1007/s11852-019-00693-z) contains supplementary material, which is available to authorized users.

Liwen Zhang

lwzhang@yic.ac.cn

1 CAS Key Laboratory of Coastal Environmental Processes and Ecological Remediation, Yantai Institute of Coastal Zone Research (YIC), Chinese Academy of Sciences(CAS), Shandong Key Laboratory of Coastal Environmental Processes, YICCAS, Yantai, Shandong 264003, People's Republic of China

2 University of Chinese Academy of Sciences, Beijing 100049, China alters community composition, degrades species diversity (including plant and benthic animals) and deteriorates ecosystem structure and function in coastal wetlands (Crain 2007; Deegan et al. 2012; Fitch et al. 2009; Graham and Mendelssohn 2010, 2016; Hunter et al. 2008; McFarlin et al. 2008).

Nitrogen addition reversed the direction of species competition outcomes, i.e., the superior competitor in low-nutrient condition was out-competed under nitrogen enrichment (Levine et al. 1998a). Species requiring facilitation (the mitigation of environmental stress by neighbour species) were able to survive without facilitation under nitrogen enrichment treatments (Levine et al. 1998b). A study about the effect of nitrogen enrichment and salinity on species distributions in a New England marsh (USA) found that the salt tolerant species that were out-competed by neighbours in the low salinity environment were able to outcompete their neighbours under nitrogen enrichment (Emery et al. 2001). Therefore, the change of competitive outcomes with nutrient enrichment can reduce species richness at the local scale. Furthermore, some studies have reported the influences of nitrogen enrichment on community composition, not just species richness (Graham and Mendelssohn 2010; Traut 2005). 
Several studies have reported eutrophication-related enhancement of the spread of invasive species in coastal wetlands (Thiebaut 2005; Zhao et al. 2015). The enhancement of N inputs caused the acceleration of the spread of $S$. alterniflora in Willapa Bay and San Francisco Bay (USA) (Tyler et al. 2007). Nitrogen enrichment through human activities had facilitated the spread of the invasive species Phragmites australis from the high marsh (low salinity) to the low marsh (high salinity) of New England salt marshes, USA (Minchinton and Bertness 2003; Silliman and Bertness 2004). Because eutrophication may enhance the salinity tolerance of invasive species or alleviate competition for nutrients between invasive species and native species, and thus promote the spread of invasive species.

The Yellow River Delta is one of the three most famous and ecologically important river deltas (the Yellow River Delta, the Yangzi River Delta, and the Pearl River Delta) in China. Its coastal wetlands are located at the intersection of the Yellow River and the Bohai Gulf. Coastal wetlands of the Yellow River Delta include plenty of freshwater and marine biological resources, such as the luxuriant vegetation and a large number of fish, which make the delta an important winter habitat for water birds ( $\mathrm{Li}$ et al. 2006). Thus, the health of coastal wetlands is very important to economic and social development, and the biodiversity conservation of this region.

S. alterniflora is a native species in the coastal wetlands of western Atlantic, and it was introduced into China in 1970s. It was the only salt marsh plant species identified in the first list of invasive species announced by the Ministry of Environmental Protection of the People's Republic of China in 2003. This species has spread from south to north China and occupies large area of China's coastal wetland. The intrusion of $S$. alterniflora has changed the physical and chemical properties of the soil, degraded habitats, reduced biodiversity, and destroyed aquaculture sites within the coastal wetlands in China (Wang et al. 2016; Zhao et al. 2014). S. alterniflora was introduced into the Yellow River Delta in 1990 to protect the shoreline from erosion. In 2007, the Spartina distribution area was only 614.59 ha (Yu et al. 2009), which increased to 1000 ha in 2012 (Ren et al. 2014), and 3692.07 ha in 2016 (Lu and Yang 2018).

The soil of the Yellow River Delta coastal wetlands was nutrient-poor, and the average of total $\mathrm{N}, \mathrm{NH}_{4}-\mathrm{N}, \mathrm{NO}_{3}-\mathrm{N}$ and total $\mathrm{P}$ concentration were $419.37 \mathrm{mg} / \mathrm{kg}, 3.274 \mathrm{mg} / \mathrm{kg}$, $0.87 \mathrm{mg} / \mathrm{kg}$ and $500.86 \mathrm{mg} / \mathrm{kg}$, respectively (Yu et al. 2010), and thus $\mathrm{N}$ and $\mathrm{P}$ are likely to limit the growth of plant in this region. On the other hand, the eutrophication process is ongoing in the region of Yellow River Delta, because the nutrient input in agriculture is very heavy, for example, the amount of $\mathrm{N}$ application is about $20 \mathrm{~g} / \mathrm{m}^{2} / \mathrm{yr}$. These nutrients are discharged into wetlands along with farmland wastewater. However, few studies have investigated whether $S$. alterniflora could invade towards non-tidal wetlands in the Yellow River Delta under the background of nutrient enrichment. Therefore, the objective of this study is to find out whether the eutrophication will favor the invasion of $S$. alternifora in the non-tidal zones of Yellow River Delta. Based on the previous studies, we predict that nutrient addition will promote the performances and spread of S. alterniflora in the non-tidal wetlands. To evaluate the prediction, S. alterniflora seedlings were transplanted from the low marsh into non-tidal wetlands, and field experiments were conducted to test influences of four manipulated variables: $\mathrm{N}$ addition, $\mathrm{P}$ addition, with/without neighbours and vegetative zones on the performances of $S$. alterniflora.

\section{Methods}

The field experiment was conducted in the Yellow River Delta National Reserve $\left(37^{\circ} 40^{\prime} \mathrm{N} \sim 38^{\circ} 10^{\prime} \mathrm{N}, 118^{\circ} 41^{\prime} \mathrm{E} \sim 119^{\circ} 16^{\prime} \mathrm{E}\right)$, which is located in Shandong province, northeast China, and the location of the study site is shown in Fig. 1a. The climate of this region was warm-temperate, with an average annual temperature of $12.2^{\circ} \mathrm{C}$. The average annual precipitation was

(a) The location of the study site

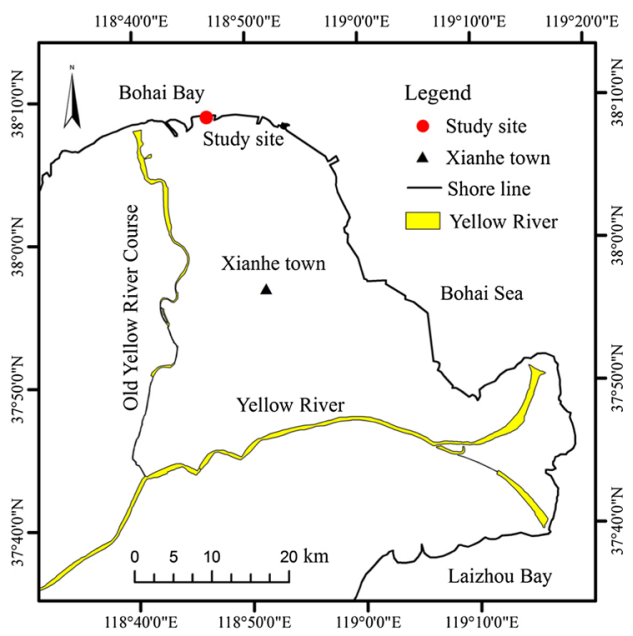

(b) The vegetation of the study site

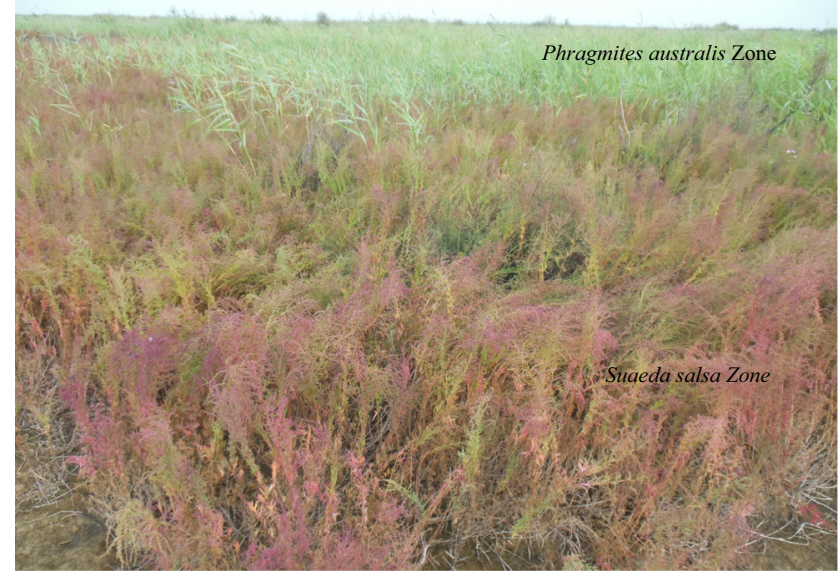

Fig. 1 The location (a) and vegetative zones (b) of the study size (Photo credit: Liwen Zhang) 
$609.5 \mathrm{~mm}$, and precipitation falling was mainly in the summer (Song et al. 2016). The invasive species S. alterniflora was found in the low marsh of the Yellow River Delta coastal wetlands. The dominant plant species, Suaeda salsa and P. australis, form distinct plant zones in the non-tidal wetland (Fig. 1b), and this area has not invaded by S. alterniflora currently. The elevation of the $P$. australis zone is higher than the $S$. salsa zone, and the $S$. salsa zone is near the sea, but not inundated by tides because the tides are inhibited by the road (Fig. 2a). This kind of non-tidal wetland was very common in the Yellow River delta because of road construction. The soil salinity within the $S$. salsa zone was higher than the
P. australis zone, and precipitation-induced water logging occurred yearly in the P. australis zone from late July to August, but not in the $S$. salsa zone.

\section{Field Experiment}

A split-plot experiment was employed in this study (Fig. 2a). Seedlings of S. alterniflora were transplanted, and $\mathrm{N}$ addition, $\mathrm{P}$ addition, and neighbour manipulations were performed in the $P$. australis and $S$. salsa zone (3 blocks were in each zone, Fig. 2b) for two years (2013 and 2014). The $\mathrm{N}$ and $\mathrm{P}$ addition treatments included three levels each: $0 \mathrm{~g} / \mathrm{m}^{2} / \mathrm{yr}$. (i.e., the control,

(a) Field experiment design

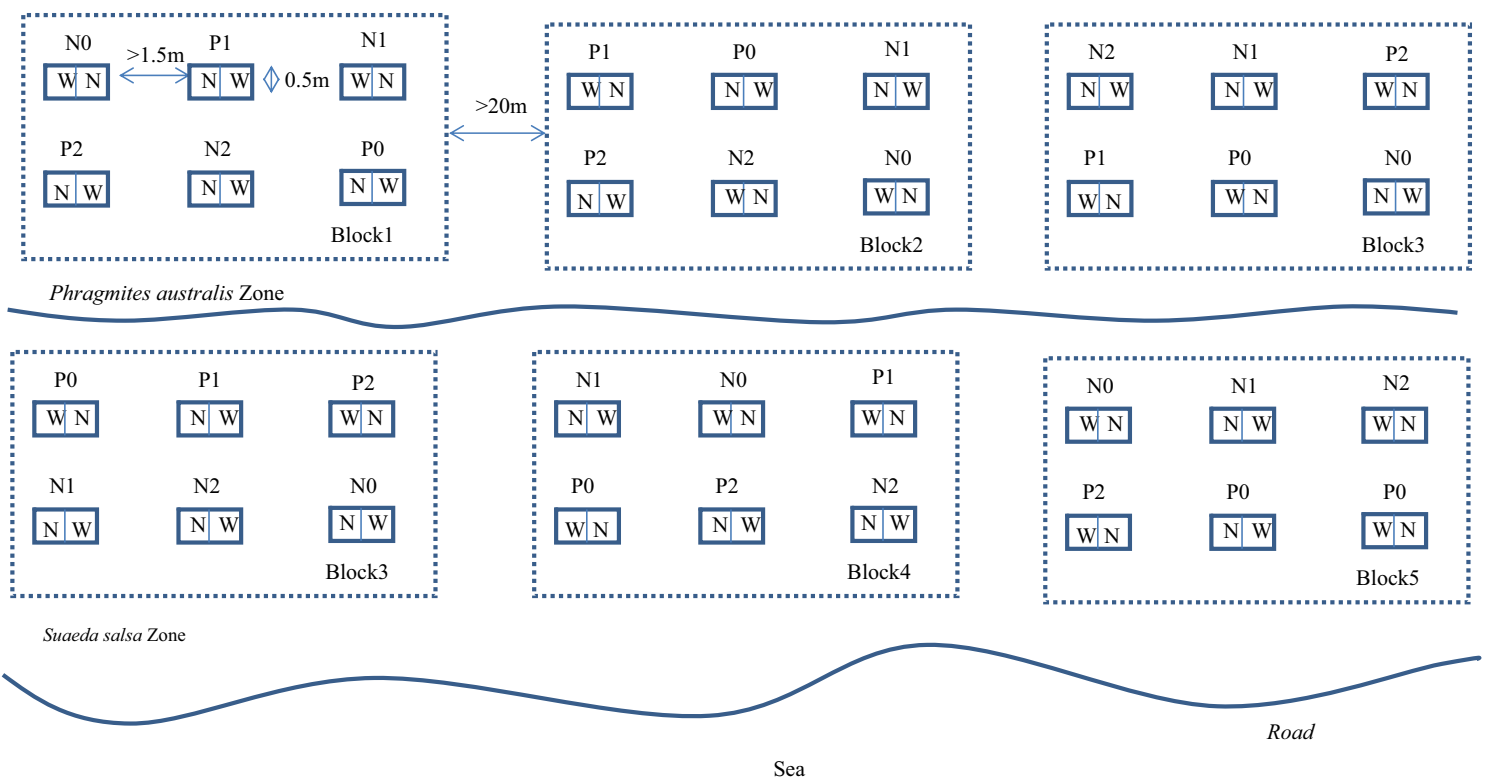

(b) Photographs of the field experiment

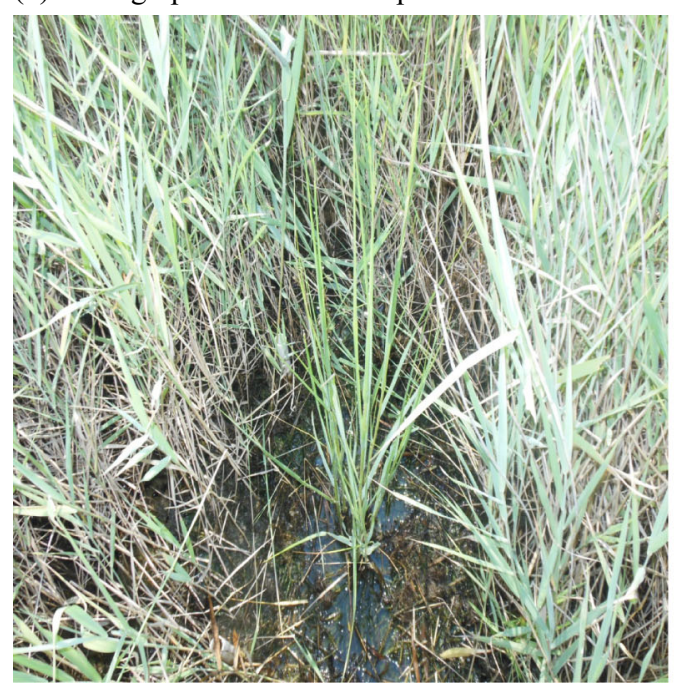

Fig. 2 Field experiment design (a) and photographs of the field experiment (b): S. alterniflora transplanted in Phragmites australis zone and Suaeda salsa zone. "N1", "N1", "N2" and "N3" mean nitrogen addition of $0,5 \mathrm{~g} / \mathrm{m}^{2} / \mathrm{yr}$. and $15 \mathrm{~g} / \mathrm{m}^{2} / \mathrm{yr}$. in the plot

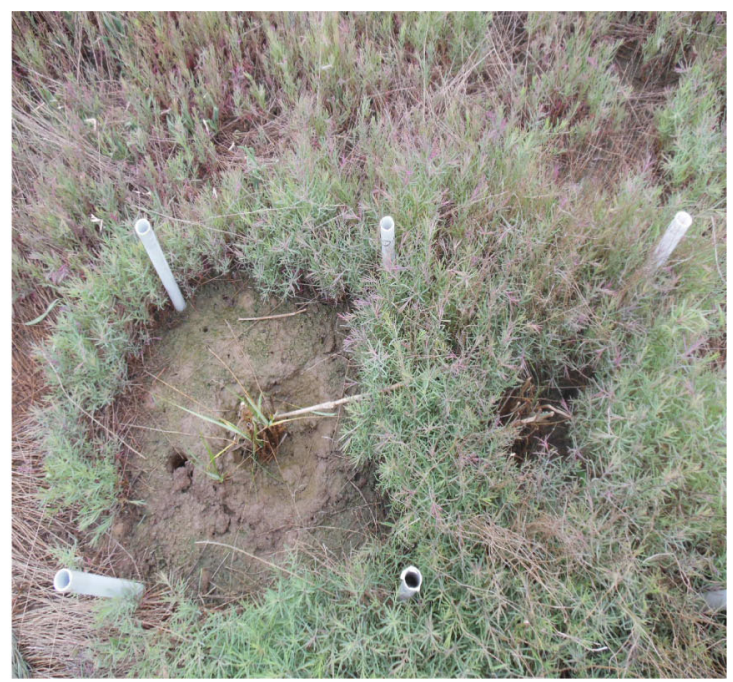

respectively, and "P1", "P2" and "P3" denote phosphorous addition of $0,5 \mathrm{~g} / \mathrm{m}^{2} / \mathrm{yr}$. and $15 \mathrm{~g} / \mathrm{m}^{2} / \mathrm{yr}$. in the plot respectively. "W" is withneighbour treatment and " $\mathrm{N}$ " is without-neighbour treatment. Photo credit: Liwen Zhang 
Table 1 The linear mixed effects model predicting influences on average biomass per stem of Spartina alterflora

\begin{tabular}{llllll}
\hline Effects & Sum square & Mean square & Df & F-value & P value \\
\hline Fixed effects & & & & & \\
Zone & 12.536 & 12.536 & 1 & 7.991 & $0.047^{*}$ \\
NP & 10.769 & 2.154 & 5 & 1.373 & 0.240 \\
NB & 2.195 & 2.195 & 1 & 1.399 & 0.239 \\
Zone:NP & 7.833 & 1.567 & 5 & 0.999 & 0.422 \\
Zone:NB & 1.988 & 1.988 & 1 & 1.267 & 0.263 \\
NP:NB & 4.539 & 0.908 & 5 & 0.579 & 0.716 \\
Zone:NP:NB & 10.997 & 2.199 & 5 & 1.402 & 0.229 \\
& Chi squre & Chi Df & P value & & \\
Random effects & & & & & \\
Block & 3.675 & 1 & 0.055 & & \\
Year & 8.794 & 1 & $0.003^{*}$ & & \\
\hline
\end{tabular}

Plant vegetative zones (Zone), $\mathrm{N}$ and $\mathrm{P}$ enhancements (NP), the neighbour treatments $(\mathrm{NB})$ and their interactions were set as fixed-effect factors, and Block and Year were set as random-effect factors. "Vegetative zones" includes the Phragmites australis and Suaeda salsa zone. "Year" includes 2013 and 2014. "Neighbour" includes treatments with and without neighbours

$\iota^{*}$, indicates $p$ value $<0.05$

N0, or P0), $5 \mathrm{~g} / \mathrm{m}^{2} / \mathrm{yr}$. (N1 or P1) and $15 \mathrm{~g} / \mathrm{m}^{2} / \mathrm{yr}$. (N2 or P2). The neighbour treatment included two levels: with/without neighbours. For without-neighbours treatment, the surrounding plants (native species: $P$. australis or $S$. salsa) were removed. In total, there were $720.5 \mathrm{~m} \times 0.5 \mathrm{~m}$ plots (Fig. 2a).

In May 2013, seventy-two $0.16 \mathrm{~m} \times 0.16 \mathrm{~m} \times$ $0.16 \mathrm{~m} \mathrm{~S}$. alterniflora seedling blocks were excavated and transplanted to the center of each experimental plots. After transplantation, seedling blocks were watered daily with fresh water for one week to avoid transplant shock (Crain et al. 2004) and ensured transplant survival for the experiment. Surrounding plants were removed every two weeks for the withoutneighbours level of the neighbour treatment. $\mathrm{N}$ (urea, $\mathrm{H}_{2} \mathrm{NCONH}_{2}\left(\mathrm{CO}\left(\mathrm{NH}_{2}\right)_{2}\right)$, for urea was the main fertilizer used in the agriculture in this region) and $\mathrm{P}\left(\mathrm{Ca}\left(\mathrm{H}_{2} \mathrm{PO}_{4}\right)_{2} \cdot \mathrm{H}_{2} \mathrm{O}\right)$ were hand-casted to the plots in June 2013. In June, the electric conductivity (EC), as well as the maximum height and number of living stems for each $S$. alterniflora within each plot were measured. In September 2013, the status (i.e., alive, inflorescent, or dead) were recorded and harvested the live stems of each $S$. alterniflora within each plot. The stems were oven-dried for $72 \mathrm{~h}$ at $70{ }^{\circ} \mathrm{C}$ to obtain the dry biomass. The dead S. alterniflora individuals were removed and replaced them with living individuals in May 2014, and then repeated the 2013 experiments.

\section{Data analysis}

According to the experiment design, linear mixed-effects models were used to analyze the effects of vegetative zones, $\mathrm{N}$ and $\mathrm{P}$ enhancements, the neighbour treatments, years and blocks and the interaction of blocks and nutrient addition on the growth (biomass per stem, change in number of plant stems, change in maximum plant height) of $S$. alterniflora, and the best-fit model was selected. Vegetative zones, $\mathrm{N}$ and $\mathrm{P}$ enhancements, the neighbour treatments and their interactions were set as fixed-effects factors. Years, blocks and the interaction of blocks and nutrient addition were set as randomeffects factors. The post-hoc Tukey HSD multiple comparisons method was employed to compare means of significant treatment levels. Generalized linear mixed-effects models were employed to analyze the effects of vegetative zones, $\mathrm{N}$
Table 2 The linear mixed effects model predicting influences on change in number of plant stems of Spartina alterflora

\begin{tabular}{llllll}
\hline Effects & Sum square & Mean square & Df & F-value & P value \\
\hline Fixed effects & & & & & \\
Zone & 109.428 & 109.428 & 1 & 3.943 & 0.116 \\
NP & 226.692 & 45.338 & 5 & 1.634 & 0.158 \\
NB & 20.984 & 20.984 & 1 & 0.756 & 0.387 \\
Zone:NP & 156.033 & 31.207 & 5 & 1.125 & 0.353 \\
Zone:NB & 12.206 & 12.206 & 1 & 0.440 & 0.509 \\
NP:NB & 159.176 & 31.835 & 5 & 1.147 & 0.341 \\
Zone:NP:NB & 85.785 & 17.157 & 5 & 0.618 & 0.686 \\
& Chi square & Chi Df & P value & & \\
Random effects & & & & & \\
Block & 19.677 & 1 & $<0.001^{* * * *}$ & & \\
Year & 23.537 & 1 & $<0.001^{* * * *}$ & & \\
\hline
\end{tabular}

Plant vegetative zones (Zone), $\mathrm{N}$ and $\mathrm{P}$ enhancements (NP), the neighbour treatments $(\mathrm{NB})$ and their interactions were set as fixed-effect factors, and Block and Year were set as random-effect factors. "Vegetative zones" includes the Phragmites australis and Suaeda salsa zone. "Year" includes 2013 and 2014. "Neighbour" includes treatments with and without neighbours

‘***, denotes $\mathrm{p}$ value $<0.001$ 
Table 3 The linear mixed effects model predicting influences on change in maximum plant height of Spartina alterflora

\begin{tabular}{llllll}
\hline Effects & Sum square & Mean square & Df & F-value & P value \\
\hline Fixed effects & & & & & \\
Zone & 3551.3 & 3551.3 & 1 & 5.162 & 0.085 \\
NP & 1372.7 & 274.5 & 5 & 0.399 & 0.848 \\
NB & 0.5 & 0.5 & 1 & 0.001 & 0.978 \\
Zone:NP & 3082.4 & 616.5 & 5 & 0.896 & 0.487 \\
Zone:NB & 1266.9 & 1266.9 & 1 & 1.841 & 0.178 \\
NP:NB & 4825.4 & 965.1 & 5 & 1.403 & 0.230 \\
Zone:NP:NB & 1610.6 & 322.1 & 5 & 0.468 & 0.799 \\
& Chi square & Chi Df & P value & & \\
Random effects & & & & & \\
Block & 39.797 & 1 & $<0.001^{* * *}$ & & \\
Year & 66.037 & 1 & $<0.001^{* * *}$ & & \\
\hline
\end{tabular}

Plant vegetative zones (Zone), $\mathrm{N}$ and $\mathrm{P}$ enhancements (NP), the neighbour treatments (NB) and their interactions were set as fixed-effect factors, and Block and Year were set as random-effect factors. "Vegetative zones" includes the Phragmites australis and Suaeda salsa zone. "Year" includes 2013 and 2014. "Neighbour" includes treatments with and without neighbours

‘***, denotes $\mathrm{p}$ value $<0.001$

and $\mathrm{P}$ enhancement, the neighbour treatments, years and blocks on the survival and inflorescence of S. alterniflora, because of the binomial distribution of the dependent variables (survival and inflorescence). Multiple models were compared and the best-fit model was selected according to AIC values. One-way ANOVA was used to analyze the difference of electric conductivity between vegetative zones or years. All the above analyses were conducted in $\mathrm{R}$ i386 3.5.2, and the package "ImerTest" was used to perform the linear mixedeffects models (R Development Core Team 2017).

\section{Results}

No significant effects of $\mathrm{N}$ and $\mathrm{P}$ enhancement were found on the average biomass per stem $(\mathrm{F}$-value $=1.373, P$ value $=$ 0.240 , Table 1), change in number of plant stems (F-value $=$ 1.634 , $\mathrm{P}$ value $=0.158$, Table 2), change in maximum plant height $(\mathrm{F}$-value $=0.399, P$ value $=0.848$, Table 3$)$, survival $($ Chi-square $=15.180, \mathrm{P}$ value $=0.126$, Table 4$)$, and inflorescences $($ Chi-square $=6.907, P$ value $=0.734$, Table 5) of $S$. alterniflora. Neighbour treatments also had no significant effect on the average biomass per stem $(\mathrm{F}$-value $=1.399$, $P$ value $=0.239$, Table 1$)$, change in number of plant stems $(F-$ value $=0.756, P$ value $=0.387$, Table 2 ), change in maximum plant height $(\mathrm{F}-$ value $=0.001, P$ value $=0.978$, Table 3$)$, survival $($ Chi-square $=10.325$, P value $=0.587$, Table 4$)$, and inflorescences $($ Chi-square $=6.110, P$ value $=0.910$, Table 5$)$ of S. alterniflora (Appendices Fig. S1). Additionally, the interaction of nutrient addition and neighbour treatments also had no significant effect on the performances of $S$. alterniflora, thus nutrient addition may not change the species interactions between $S$. alterniflora and native species.

However, the variation in biomass per stem was found to be explained best by a fixed-effect factor: vegetative zones and the random-effect factor (i.e. year), with a higher biomass per stem found in the $P$. australis zone than the $S$. salsa zone $(1.86 \pm 0.17 \mathrm{~g}$ vs. $0.82 \pm 0.15 \mathrm{~g}, P$ value $<0.05$, Table 1 and Fig. $3 \mathrm{a}$ ) and with a higher biomass per stem found in 2013 than $2014(1.72 \pm 0.19 \mathrm{~g}$

Table 4 Comparison and selection of the general linear mixed effects models predicting influences on survival of Spartina alterflora

\begin{tabular}{|c|c|c|c|c|}
\hline Models & AIC & Chi-square & Chi-df & $\mathrm{P}$ value \\
\hline Model1:Survival $(1 \mid$ Block $)+(1 \mid$ Year $)$ & 186.11 & & & \\
\hline Model2:Survival $\sim$ Zone $+(1 \mid$ Block $)+(1 \mid$ Year $)$ & 175.12 & 12.992 & 1 & $<0.001^{* * * *}$ \\
\hline Model3:Survival $\sim$ Zone $*$ NP $+(1 \mid$ Block $)+(1 \mid$ Year $)$ & 179.94 & 15.180 & 10 & 0.126 \\
\hline Model4:Survival $\sim$ Zone $*$ NP $*$ NB $+(1 \mid$ Block $)+(1 \mid$ Year $)$ & 193.61 & 10.325 & 12 & 0.587 \\
\hline
\end{tabular}

Plant vegetative zones (Zone), $\mathrm{N}$ and $\mathrm{P}$ enhancements (NP), the neighbour treatments (NB) and their interactions were set as fixed-effect factors, and Block and Year were set as random-effect factors. "Vegetative zones" includes the Phragmites australis and Suaeda salsa zone. "Year" includes 2013 and 2014. "Neighbour" includes treatments with and without neighbours

‘***, denotes $\mathrm{p}$ value $<0.001$ 
Table 5 Comparison and selection of the general linear mixed effects models predicting influences on the inflorescences of Spartina alterflora

\begin{tabular}{llll}
\hline Models & AIC & Chi-square & Chi-df \\
\hline Model1:Inflorescences $\sim(1 \mid$ Block $)+(1 \mid$ Year $)$ & 95.971 & & \\
Model2:Inflorescences $\sim$ Zone + (1 | Block $)+(1 \mid$ Year $)$ & 92.037 & 5.934 & 1 \\
Model3:Inflorescences $\sim$ Zone * NP + (1 | Block $+(1 \mid$ Year $)$ & 105.130 & 6.907 & $0.015^{*}$ \\
Model4:Inflorescences $\sim$ Zone * NP * NB + (1| Block $)+(1 \mid$ Year $)$ & 123.020 & 6.110 & 0.734 \\
\hline
\end{tabular}

Plant vegetative zones (Zone), $\mathrm{N}$ and $\mathrm{P}$ enhancements (NP), the neighbour treatments (NB) and their interactions were set as fixed-effect factors, and Block and Year were set as random-effect factors."Vegetative zones" includes the Phragmites australis and Suaeda salsa zone. "Year" includes 2013 and 2014. "Neighbour" includes treatments with and without neighbours

:*, denotes p value $<0.05$

vs. $0.91 \pm 0.13 \mathrm{~g}, P$ value $<0.05$, Table 1 and Fig. $4 \mathrm{a})$. Variation of change in individuals of $S$. alterniflora and change in maximum plant height from June to September

(a) Biomass per stem

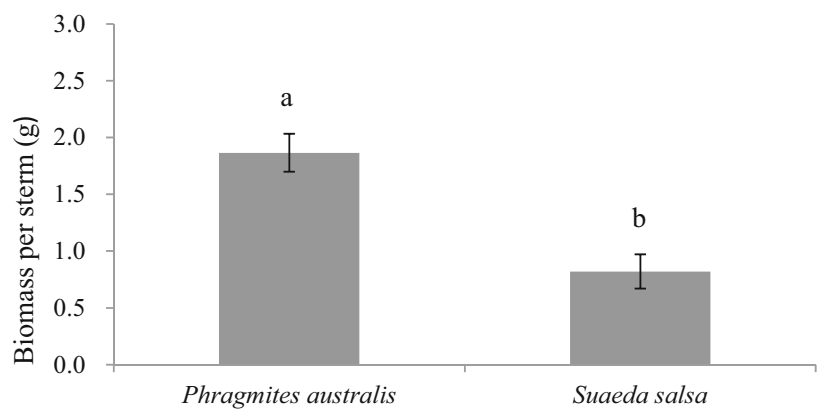

(b) Survival

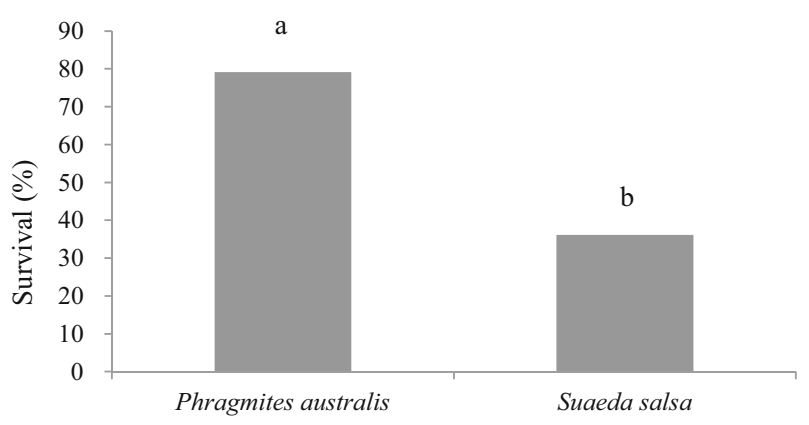

(c) Inflorescences

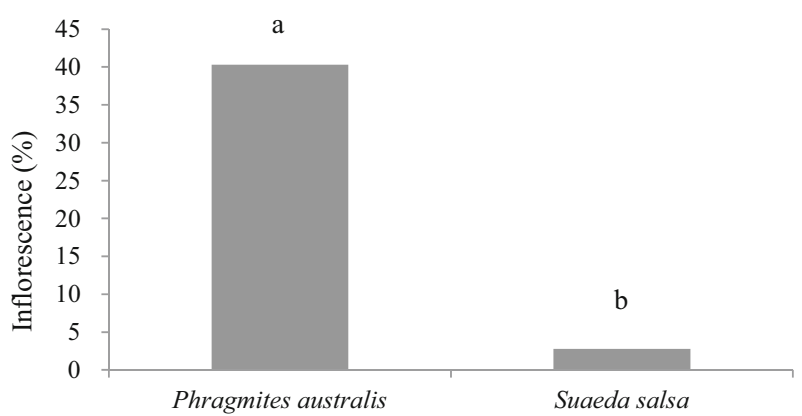

Fig. 3 The variation in the performances (biomass per stem, survival and inflorescences) of $S$. alterniflora from different vegetative zones. The error bar is \pm SE and $n=72$ were only significantly influenced by random-effect factors: block and year (with less dead individuals found in 2013 than $2014,-1.17 \pm 0.70$ stems vs. $-7.49 \pm 0.91$ stems, $\mathrm{P}$ value $<0.05$; with a higher maximum plant height changed found in 2013 than 2014, 39.63 \pm $6.59 \mathrm{~cm}$ vs. $-16.20 \pm 3.08 \mathrm{~cm}, \mathrm{P}$ value $<0.05$; Tables 2, 3 and Fig. 4b, c).

Vegetative zones also had a significant effect on survival of S. alterniflora, with a higher level of survival found in the $P$. australis zone than the $S$. salsa zone(survivorship $79 \%$ vs. $36 \%$, $\mathrm{P}$ value $<0.05$; Table 4 and Fig. $3 \mathrm{~b}$ ), also with a higher level of survival found in 2013 than 2014 (survivorship 65\% vs. $50 \%$, P value $<0.05$; Table 4 and Fig. $4 \mathrm{~d}$ ). The inflorescence status of $S$. alterniflora was significantly affected by vegetative zones (with more inflorescence present in the $P$. australis zone than the $S$. salsa zone, $40 \%$ vs. $2 \%$ plots, $\mathrm{P}$ value $<0.05$; Table 5 and Fig. $3 \mathrm{c}$ ), and also with a higher level of inflorescence found in 2013 than 2014 (inflorescence: 36\% vs. $6.94 \%, \mathrm{P}$ value $<0.05$; Table 5 and Fig. $4 \mathrm{e}$ ).

Moreover, the soil salinity was higher in the $S$. salsa than the $P$. australis zone $(10.92 \pm 0.32 \mathrm{mS} / \mathrm{cm}$ vs. $6.90 \pm 0.17 \mathrm{mS} /$ $\mathrm{cm}, \mathrm{F}$-value $=9.12, \mathrm{P}$ value $<0.001 ;$ Appendices Fig. S2), and it was also higher in 2014 than in $2013(9.59 \pm 0.36 \mathrm{mS} / \mathrm{cm}$ vs. $8.19 \pm 0.32 \mathrm{mS} / \mathrm{cm}, \mathrm{F}$-value $=124.95, \mathrm{P}$ value $<0.01$; Appendices Fig. S2).

\section{Discussion}

It was surprising that nutrients enhancement including $\mathrm{N}$ and $P$ had no effect on the survival, growth and inflorescence of S. alterniflora. $\mathrm{N}$ and $\mathrm{P}$ addition also did not influence the species interactions in our study. However, evidences in $\mathrm{N}$ enhancement-related spreading of invasive plant species were accumulating from plant communities of a variety of ecosystems (Davis et al. 2000; Fenn et al. 2003). Nitrogen addition had been shown to increase the aboveground biomass of S. alterniflora in its native habitat within the United States (Buresh et al. 1980; Darby and Turner 2008; Tyler et al. 2003) and within non-native habitats, such as in the Willapa 
(a) Biomass per stem

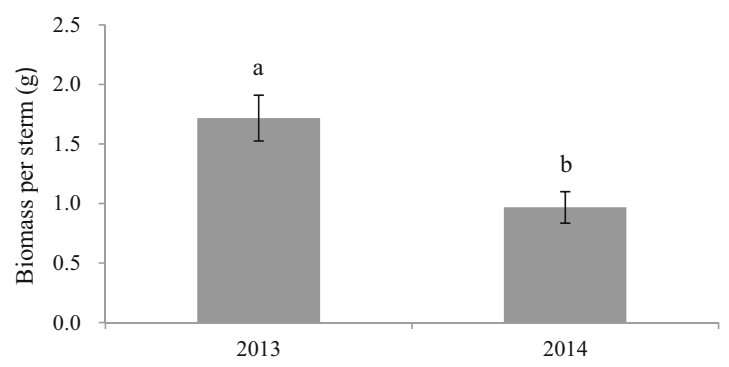

(b) Chang in number of plant stems

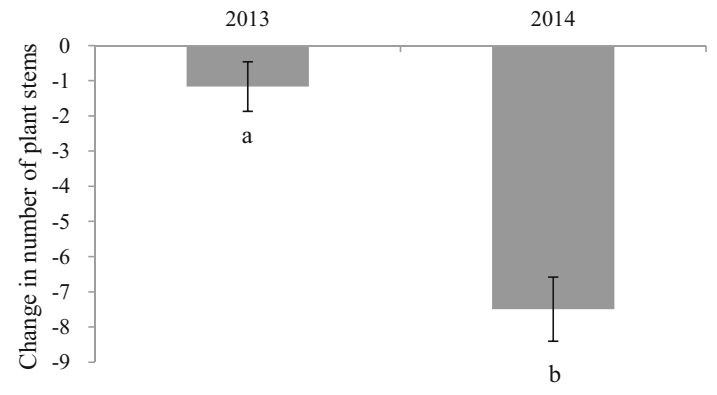

(d) Survival

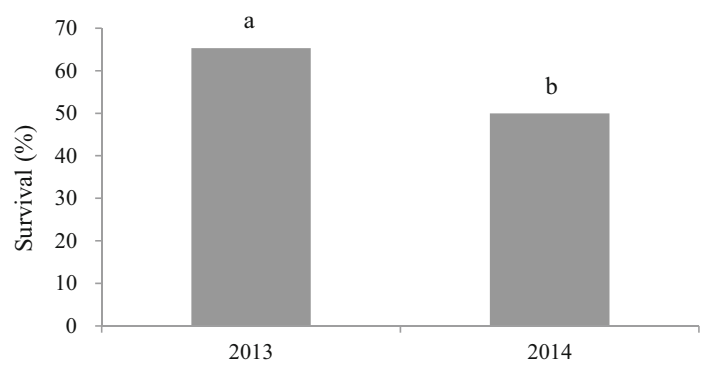

(e) Inflorescences

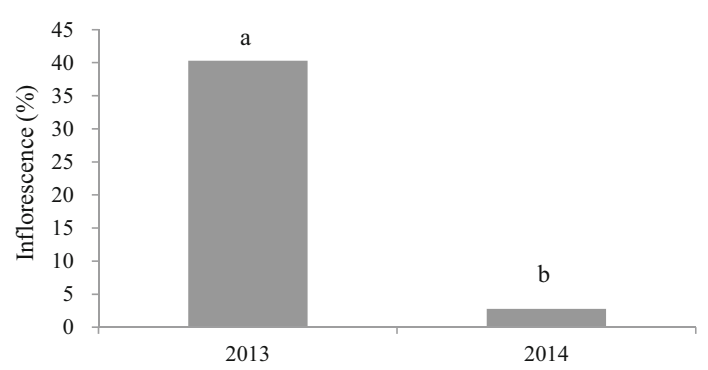

(c) Change in maximum plant height

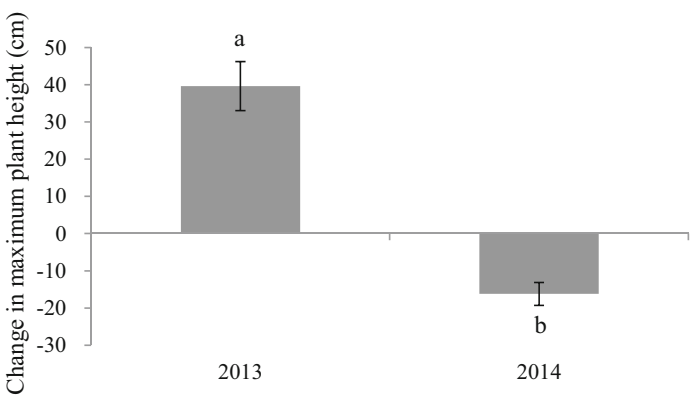

Fig. 4 The variation in the performances (biomass per stem, survival and inflorescences) of S. alterniflora between 2013 and 2014 . The error bar is \pm SE and $n=72$

Bay and San Francisco Bay in the United States (Tyler et al. 2007) and in China (Zhao et al. 2015). Nitrogen enrichment also had the potential to improve competitive ability of invasive species, allowing them to outcompete native species (Allen et al. 2018; Chambers et al. 2007; James et al. 2008; Pennings et al. 2002; Tyler et al. 2007). The disparity may be due to the environmental conditions of the study sites. The experiments in those studies were conducted in the low marsh or mud flat, and the environmental factors were very different between the low marsh and the non-tidal wetland. In the low marsh, the tide flooded every day even twice a day, however, in the non-tidal wetland in the Yellow River Delta, the flooding frequencies was much lower. Direct evidence from a manipulative experiment showed that elevated inundation flooding frequencies can promote the spread of S. alterniflora (Xue et al. 2018). Additionally, a study reported that salinity induced by less flooding frequency in high marsh, but not competition was suggested to be the most important factor suppressing the spread of this smooth cordgrass, although $S$. alterniflora can tolerant high salinity (He et al. 2012). Nutrient enrichment may increase the salinity and drought tolerance of plants by increasing proline levels within plant cells, mediating osmotic equilibrium and increasing water use efficiency (Levine et al. 1998a, b), but this mechanism did not work in our study. Therefore, the environmental condition of the low flooding frequency may overwhelm the effect of nutrient and inhibit the performances of $S$. alterniflora in the non-tidal wetlands.

The presence of neighbours also did not significantly influence the survival and growth of $S$. alterniflora in our study. The limited effect of neighbours may have been due to attenuation of drought or salinity effects on $S$. alterniflora growth in the presence of neighbours. These results were, to some extent, consistent with previous studies, which have argued that nitrogen enrichment can reverse the competitive dominance hierarchy of species (Emery et al. 2001; Levine et al. 1998a, b). 
Nevertheless, the performance outcomes of species interactions between invasive and native species were still competitions but not facilitations under the condition of nitrogen addition, however, the intensity of competition reduced.

The results showed that the only fixed-effect factor significantly influenced the survival and growth of $S$. alterniflora in the non-tidal wetland was vegetative zone. The survival, growth and reproduction performances of $S$. alterniflora in the $P$. australis zone were better than the $S$. salsa zone. Especially, most of the $S$. alterniflora could not survive in the S. salsa zone in 2014. Soil moisture and salinity may be the reason. The moisture in the soil of the $S$. salsa zone was much lower than the low marsh which was flooded by the tide daily, and water-logging occurred from late July to August in the $P$. australis zone which made the water level in the $P$. australis zone higher than that in the $S$. salsa zone. Salinity in the $S$. salsa zone was higher than in the P. australis zone. $S$. alterniflora is sensitive to water content, in S. alterniflora native habitat in the the USA, prolonged drought and elevated salinity also could lead to the dieback of S. alterniflora (Marsh et al. 2016). Salinity and drought likely restricted the survival and growth of S. alterniflora in the S. salsa zone.

The random-effect factor: year was also an important factor influencing the survivor and growth of S. alterniflora in the nontidal wetland. Plant performance measurements in 2013 were suggestive of superior overall performance than in 2014. The follow reasons may cause this result. Firstly, the strong effect of year may also be due to variation in salinity, and salinity in 2014 was higher than in 2013 within the same vegetative zone (appendixes Fig. S2 and S3). Secondly, seasonal differences may matter for S. alterniflora. The growth in S. alterniflora was strongly seasonal, even in places without strong seasonal temperature differences (Hill and Roberts 2017). This may affect their seasonal leaf tissue concentrations and thus their nutrient limitation status and the response to nutrient addition.

\section{Conclusions}

After two-year experiment, we found $\mathrm{N}$ and $\mathrm{P}$ enrichments were unlikely to promote the spread of S. alterniflora toward the Yellow River Delta non-tidal wetland. This result may attribute to the combination of the less flooding frequency and high salinity in the non-tidal wetland. Therefore, the control and management of S. alterniflora invasion should focus on the spread of S. alterniflora in low marsh of tidal wetlands.

Acknowledgements This research is funded by the Foundation for Outstanding Young Scientist in Shandong Province (No.BS2013HZ012) and the Youth Innovation Promotion Association CAS (2018247). We thank Christine Verhille at the University of British Columbia for her assistance with English language and grammatical editing of the manuscript and we also thank Jingjing Wu for her assistance with drawing the location map.

\section{References}

Allen WJ, Meyerson LA, Flick AJ, Cronin JT (2018) Intraspecific variation in indirect plant-soil feedbacks influences a wetland plant invasion. Ecology 99:1430-1440

Brin LD, Valiela I, Goehringer D, Howes B (2010) Nitrogen interception and export by experimental salt marsh plots exposed to chronic nutrient addition. Mar Ecol Prog Ser 400:3-17. https://doi.org/10. 3354/meps 08460

Buresh RJ, Delaune RD, Patrick WHJR (1980) Nitrogen and phosphorus distribution and utilization by Spartina Alterniflora in a Louisiana Gulf Coast Marsh. Estuaries 3:111-121. https://doi.org/10.2307/ 1351555

Chambers JC, Roundy BA, Blank RR, Meyer SE, Whittaker A (2007) What makes Great Basin sagebrush ecosystems invasible by Bromus tectorum? Ecol Monogr 77:117-145. https://doi.org/10. 1890/05-1991

Crain CM (2007) Shifting nutrient limitation and eutrophication effects in marsh vegetation across estuarine salinity gradients. Estuar Coast 30:26-34. https://doi.org/10.1007/Bf02782964

Crain CM, Silliman BR, Bertness SL, Bertness MD (2004) Physical and biotic drivers of plant distribution across estuarine salinity gradients. Ecology 85:2539-2549. https://doi.org/10.1890/03-0745

Darby FA, Turner RE (2008) Below- and aboveground biomass of Spartina alterniflora: response to nutrient addition in a Louisiana salt marsh. Estuar Coast 31:326-334. https://doi.org/10.1007/ s12237-008-9037-8

Davis MA, Grime JP, Thompson K (2000) Fluctuating resources in plant communities: a general theory of invasibility. J Ecol 88:528-534. https://doi.org/10.1046/j.1365-2745.2000.00473.x

Deegan LA, Johnson DS, Warren RS, Peterson BJ, Fleeger JW, Fagherazzi S, Wollheim WM (2012) Coastal eutrophication as a driver of salt marsh loss. Nature 490:388-38+. https://doi.org/10. 1038/nature 11533

Emery NC, Ewanchuk PJ, Bertness MD (2001) Competition and saltmarsh plant zonation: stress tolerators may be dominant competitors. Ecology 82:2471-2485. https://doi.org/10.2307/2679929

Fenn ME et al (2003) Ecological effects of nitrogen deposition in the western United States. Bioscience 53:404-420. https://doi.org/ 10.1641/0006-3568(2003)053[0404:Eeondi]2.0.Co;2

Fitch R, Theodose T, Dionne M (2009) Relationships among upland development, nitrogen, and plant community composition in a Maine salt marsh. Wetlands 29:1179-1188. https://doi.org/10. 1672/08-154.1

Graham SA, Mendelssohn IA (2010) Multiple levels of nitrogen applied to an oligohaline marsh identify a plant community response sequence to eutrophication. Mar Ecol Prog Ser 417:73-82. https:// doi.org/10.3354/meps 08808

Graham SA, Mendelssohn IA (2016) Contrasting effects of nutrient enrichment on below-ground biomass in coastal wetlands. J Ecol 104: 249-260. https://doi.org/10.1111/1365-2745.12498

He Q, Cui BS, An Y (2012) Physical stress, not biotic interactions, preclude an invasive grass from establishing in forb-dominated salt marshes. PLoS One 7:e33164. https://doi.org/10.1371/journal. pone. 0033164

Hill TD, Roberts BJ (2017) Effects of seasonality and environmental gradients on Spartina alterniflora allometry and primary production. Ecol Evol 7:9676-9688. https://doi.org/10.1002/ece3.3494

Howarth R et al (2000) Nutrient pollution of coastal rivers, bays, and seas. Issues in Ecology 7:1-15

Hunter A, Morris NMB, Lafabrie C, Cebrian J (2008) Effects of nutrient enrichment on Distichlis spicata and Salicornia bigelovii in a marsh salt pan. Wetlands 28:760-775. https://doi.org/10.1672/06-149.1

James JJ, Davies KW, Sheley RL, Aanderud ZT (2008) Linking nitrogen partitioning and species abundance to invasion resistance in the 
Great Basin. Oecologia 156:637-648. https://doi.org/10.1007/ s00442-008-1015-0

Levine JM, Brewer JS, Bertness MD (1998a) Nutrients, competition and plant zonation in a New England salt marsh. J Ecol 86:285-292. https://doi.org/10.1046/j.1365-2745.1998.00253.x

Levine JM, Hacker SD, Harley CDG, Bertness MD (1998b) Nitrogen effects on an interaction chain in a salt marsh community. Oecologia 117:266-272. https://doi.org/10.1007/s004420050657

Li ZH, Wang MM, Liu SR, Song GB, Gao JX (2006) Analysis about the biodiversity of Yellow River delta. Ecol Environ (Chinese version) 15:577-582

Lu F, Yang J (2018) Remote sensing monitoring and analysis of Spartina alterniflora based on Landsat 8 OLI satellite data-taken the Shandong yellow river delta national nature reserve as an example. J Shandong Forestry Sci Technol:29-32

Marsh A, Blum LK, Christian RR, Ramsey E, Rangoonwala A (2016) Response and resilience of Spartina alterniflora to sudden dieback. J Coast Conserv 20:335-350. https://doi.org/10. 1007/s11852-016-0445-9

McFarlin CR, Brewer JS, Buck TL, Pennings SC (2008) Impact of fertilization on a salt marsh food web in Georgia. Estuar Coast 31:313325. https://doi.org/10.1007/s12237-008-9036-9

Minchinton TE, Bertness MD (2003) Disturbance-mediated competition and the spread of Phragmites australis in a coastal marsh. Ecol Appl 13:1400-1416. https://doi.org/10.1890/02-5136

Pennings SC, Stanton LE, Brewer JS (2002) Nutrient effects on the composition of salt marsh plant communities along the southern Atlantic and gulf coasts of the United States. Estuaries 25:1164-1173. https:// doi.org/10.1007/Bf02692213

R Development Core Team (2017) R: a language and environment for statistical computing. R Foundation for statistical computing, Vienna, Austria. URL https://www.R-project.org. Accessed 25 Oct 2018

Ren GB, Liu YF, Ma Y, Zhang J (2014) Spartina alterniflora monitoring and change analysis in Yellow River Delta by remote sensing technology. Acta Laser Biology Sinica (Chinese version) 22:596-608

Silliman BR, Bertness MD (2004) Shoreline development drives invasion of Phragmites australis and the loss of plant diversity on New England salt marshes. Conserv Biol 18:1424-1434. https://doi.org/ 10.1111/j.1523-1739.2004.00112.x

Song DB, Yu JB, Wang GM, Han GX, Guan B, Li YZ (2016) Change characteristics of average annual temperature and annual precipitation in costal wetland region of the Yellow River Delta from 1961 to 2010. Wetland Science (Chinese version) 14:248-253
Sousa AI, Lillebo AI, Cacador I, Pardal MA (2008) Contribution of Spartina maritima to the reduction of eutrophication in estuarine systems. Environ Pollut 156:628-635. https://doi.org/10.1016/j. envpol.2008.06.022

Thiebaut G (2005) Does competition for phosphate supply explain the invasion pattern of Elodea species? Water Res 39:3385-3393. https://doi.org/10.1016/j.watres.2005.05.036

Traut BH (2005) Effects of nitrogen addition and salt grass (Distichlis spicata) upon high salt marsh vegetation in northern California, USA. Estuaries 28:286-295. https://doi.org/10.1007/Bf02732862

Tyler AC, Mastronicola TA, McGlathery KJ (2003) Nitrogen fixation and nitrogen limitation of primary production along a natural marsh chronosequence. Oecologia 136:431-438. https://doi.org/10.1007/ s00442-003-1277-5

Tyler AC, Lambrinos JG, Grosholz ED (2007) Nitrogen inputs promote the spread of an invasive marsh grass. Ecol Appl 17:1886-1898. https://doi.org/10.1890/06-0822.1

Wang C, Pei XH, Yue SS, Wen YN (2016) The response of Spartina alterniflora biomass to soil factors in Yancheng, Jiangsu Province, PR China. Wetlands 36:229-235. https://doi.org/10.1007/s13157016-0732-0

Xue L et al (2018) Elevated salinity and inundation will facilitate the spread of invasive Spartina alterniflora in the Yangtze River estuary, China. J Exp Mar Biol Ecol 506:144-154. https://doi.org/10.1016/j. jembe.2018.06.008

Yu X, Tian JY, Li JQ, Sun JK (2009) Distribution area and expanding speed of alien invasive species Spartina spp. in Yellow River Delta. Marine Environmental Science (Chinese Version) 28:684-688

Yu JB et al (2010) The spatial distribution characteristics of soil nutrients in new-born coastal wetland in the Yellow River delta. Acta Scientiae Circumstantiae (Chinese version) 30:855-861

Zhao CY, Liu XY, Bai JD, Lu FC, Li JS (2014) Impact of Spartina alterniflora on benthic macro-invertebrates communities on mangrove wetland in Xicungang Estuary, Guangxi. Biodivers Sci (chinese version) 22:630-639

Zhao H, Yang W, Xia L, Qiao YJ, Xiao Y, Cheng XL, An SQ (2015) Nitrogen enriched eutrophication promotes the invasion of Spartina alterniflora in coastal China. Clean-Soil Air Water 43:244-250. https://doi.org/10.1002/clen.201300844

Publisher's note Springer Nature remains neutral with regard to jurisdictional claims in published maps and institutional affiliations. 